\title{
A Review on Pull out Test on Exterior Beam-Column joint
}

\author{
Vrajesh M Patel[1], Dr. Suhasini Kulkarni ${ }^{[2]}$ \\ ${ }^{[1]}$ Research Scholar, Parul Institute of Engineering \& Technology, Vadodara, Gujarat, India \\ ${ }^{[2]}$ Associate Professor, Parul Institute of Engineering \& Technology, Vadodara, Gujarat, India
}

\begin{abstract}
Conventional concrete loses its tensile resistance after the formation of multiple cracks. However, fibrous concrete can sustain a portion of its resistance following cracking to resist more loading. Use of the headed bar can offer a potential solution for these problems and may also ease fabrication, construction, and concrete placement. There have been many catastrophic failures reported in the past earthquakes, with Turkey and Taiwan earthquakes occurred in 1999, which have been attributed to beam-column joint failures. To achieve this performance level, special steel reinforcement details are required in the beam-column joint region of reinforced concrete framed structures. The experimental work carried out on four different arrangements of reinforcement of beam column joints. The aim of the research is to investigate the pull-out behavior such as strength, failure mode, and crack patterns of different arrangements of reinforcement in exterior beam column junctions. The transverse reinforcement of a joint reduces stresses by improving the confinement of concrete. All joints were tested by using reversed cyclic loading. In the first arrangement, the beam bars are extended in the column for distance $\mathrm{Ld}+(10 \mathrm{xDia})$ from the inner face of column. This research studies the experimental behavior of full-scale beam-column space (three-dimensional) joints under displacement-controlled cyclic loading. Eleven joint specimens, included a traditionally reinforced one (without adequate shear reinforcement), a reference one with sufficient shear reinforcement according to ACI 318, and nine specimens retrofitted by ferrocement layers, were experimentally tested to evaluate a retrofit technique for strengthening shear deficient beam column joints.
\end{abstract}

Keywords - Beam-Column Joint, FRP, Headed Bar, Pull-Out Test, Cyclic Loading

\section{INTRODUCTION}

The beam-column joint is a crucial zone in reinforced concrete frames. It is subjected to large forces during severe ground shaking, and the behaviour of joints has a significant influence on the response of the structure. ${ }^{[1]}$ The functional requirement of a joint, which is the zone of intersection of beams and columns, is to enable the adjoining members to develop and sustain their ultimate capacity. If the joint is not carefully detailed, the beam-column joint may become a weak link. To prevent this weak link, detailing technique should be given adequate care to meet the required strength, stiffness, and ductility of RC joints. ${ }^{[2]}$

Beam column joints in a reinforced concrete moment resisting frame are crucial zones for transfer of loads effectively between the connecting elements (i.e., beams and columns) in the structure. ${ }^{[3]}$ A majority of the traditional reinforced concrete frame buildings, existing across the Middle East, lack adequate confinement in beam-column joints, or in other 
words, are shear deficient because they were constructed before the introduction of seismic codes for construction. ${ }^{[4]}$ This research studies the experimental behavior of full-scale beam-column space (three dimensional) joints under displacement controlled cyclic loading. Accordingly, bending of rebars became more and more difficult. For simplification of rebar frame assembly, especially at the congested joint regions, mechanical anchorage was developed. Many studies on exterior beamcolumn joints located at middle floors of RC buildings, where mechanical anchorage was used at the end of beam rebar, have been conducted. ${ }^{[5]}$

Previous studies revealed that structural performance of beam-column joints is influenced by not only safety margin of their shear strength but also the amount of shear reinforcement in joint and beam-tocolumn flexural strength ratio. ${ }^{[6]}$ In this study, to examine the influence of the amount of shear reinforcement on structural performance of $\mathrm{T}$-shaped beam-column joints where column longitudinal rebars were mechanically anchored, static, and cyclic loading tests were conducted using three partial frame specimens including such beam-column joints. ${ }^{[7]}$

Research carried out in previous years has enabled the development of design standards that provide seismic requirements and reinforcement detailing that result in better seismic performance of newly designed structures and minimize the probability of damage and/or collapse. As pointed out by Pantaildes et al. this can be achieved by preventing the brittle failure of joints in reinforced concrete (RC) frame structures, maintaining its integrity, and reducing its stiffness degradation. ${ }^{[8]}$ However, there is a considerable number of buildings worldwide that have been designed, detailed, and built without specific seismic requirements that may be vulnerable to seismic events, as demonstrated by recent earthquake on an existing RC structure, several strengthening techniques have been developed, studied, and applied in previous decades. ${ }^{[9]}$ Traditional techniques include concrete and steel jacketing of the frame elements; however these techniques are complex, intrusive, and labour intensive. More modern techniques such as base isolation and supplemental damping devices have also been developed, but some challenging aspects still need to be addressed such as cost, invasiveness, and practical implementation. ${ }^{[10]}$

\section{TYPES OF JOINTS}

The joint is defined as the portion of the column within the depth of the deepest beam that frames into the column. In a moment resisting frame, three types of joints can be identified viz. interior joint, exterior joint and corner joint. When four beams frame into the vertical faces of a column, the joint is called as an interior joint. When one beam frames into a vertical face of the column and two other beams frame from perpendicular directions into the joint, then the joint is called as an exterior joint. When a beam each frames into two adjacent vertical faces of a column, then the joint is called as a corner joint. The severity of forces and demands on the performance of these joints calls for greater understanding of their seismic behaviour.

These forces develop complex mechanisms involving bond and shear within the joints.
i. Interior joint
ii. Exterior joint
iii. Corner Joint

\section{PULL-OUT TEST FOR CALCULATING BOND STRESS}

i. Prepare concrete mix as per mix design for different grade of concrete.

ii. Cast the concrete cube of different grade having size of $(300 * 300 * 300) \mathrm{mm}$. Using 12 
$\mathrm{mm}, 16 \mathrm{~mm}, 20 \mathrm{~mm}$ bars having Glass fiber head of different shapes.

iii. Perform the pull-out test on Universal Testing Machine (UTM) using pull out test attachment at 28 days age.

iv. Attach a dial gauge for finding the slip between steel and concrete and draw the curve between load and slip.

v. Take the reading of load at $0.125 \mathrm{~mm}$ slip and at bond failure.

The bond stress is calculated by using the equation

$\sigma=\frac{P}{\pi \times D \times L}$

Were,

$\sigma=$ Bond Strength

$\mathrm{D}=$ Diameter of Bar

$\mathrm{L}=$ Development Length of bars

$\mathrm{P}=$ Maximum load applied from UTM

\section{JOINT REINFORCING TECHNIQUES}

With regard to the types of reinforcing methods for the joint region, ACI-352 recommend two types. They are Type I and Type II joints, which are very similar to ordinary moment resisting (OMR) and special moment resisting (SMR) frames recommended in IS: 456 and IS: 13920, respectively. Furthermore, ACI-352 recommends an alternative reinforcing method called "Headed Bars" to avoid congestion of reinforcement and to have ductile behaviour of RCC joints. The performance of exterior RC beam-column joint has been a research topic for many years. Paulay and Priestley used the laws of statics and postulated that joint shear reinforcement is necessary to sustain the diagonal compression field rather than to provide confinement to compressed concrete in a joint core. Studies have been performed by Tsonos et al. based on the experimental study on the external beamcolumn joints reinforced with inclined (lateral) bars.
It was reported that the joints acquired high strength and no appreciable deterioration were noticed after reaching their maximum capacity. Also, low joint shear stresses in the presence of high flexural strength resulted in satisfactory performance of exterior beamcolumn joints reinforced with inclined bars. Apart from these techniques, different techniques have also been tried by various researchers.

\section{MATERIAL PROPERTIES AND CONCRETE AND MIX DESIGN}

The materials required for the experimental work were tested in the laboratory to get necessary data for mix design. 53 grade Pozzolana Portland cement was used. Natural iver sand with specific gravity 2.69 and fineness modulus 3.5 which conforms to grading zone II was used as fine aggregate. Crushed basalt with maximum size of $20 \mathrm{~mm}$ and specific gravity 2.79 is used as coarse aggregate. Concrete mix design is carried out for concrete grades M30 for medium workability. The mix proportions are finalized after taking some trials for target strength determined by considering standard deviation equal to 5 .

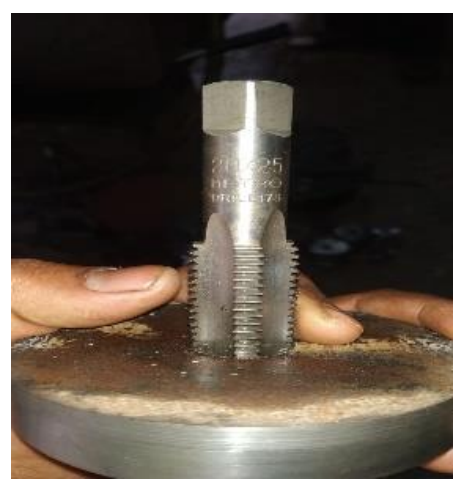

Fig 1 headed bar

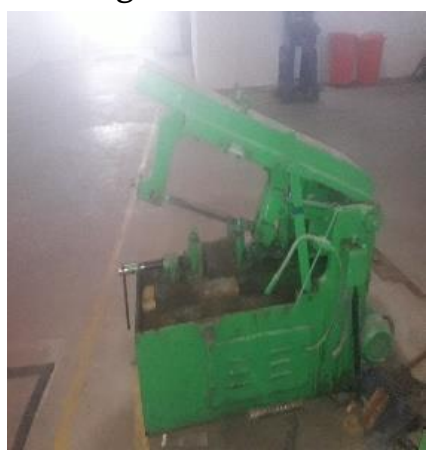

Fig 2 cutting of bar 


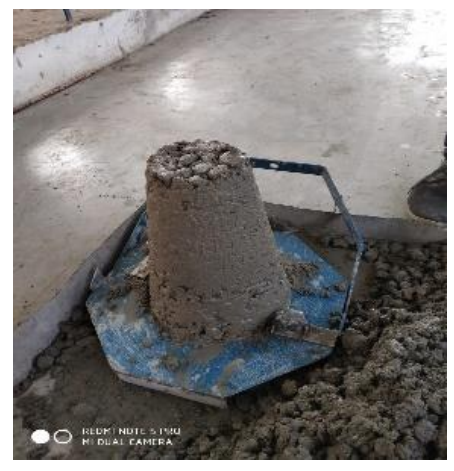

Fig 3 Slump test

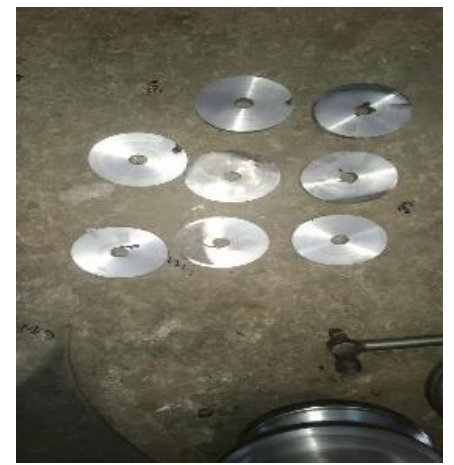

Fig 4 Metal head

\section{FIBRE REINFORCED CONCRETE}

Fibre reinforced concrete can be defined as a composite material consisting of hydraulic cements containing fine or fine and coarse aggregate and discontinuous discrete fibres. Continuous meshes, woven fabrics and long wires or rods are not considered to be discrete fibres. Fibre can de circular or flat. Fibres are often described by a convenient parameter called 'Aspect Ratio'. The aspect ratio of the fibre is the ratio of its length to an equivalent fibre diameter. Typical aspect ratio ranges from 50 to 150. Each type of fibre has its own characteristic properties and limitations. Steel fibre is one of the most used fibres. Generally, round, straight fibres are used.

\section{CONCLUSION}

Results found in FRP headed bars are good as compared with metal headed bars in different diameter of bars used with different shape and size of head. By experimental results it is found that the strength of FRP headed bars is more having different aspect ratio. For high rise building, higher grade of concrete with mix design is preferred.

\section{REFERENCES}

[1]. Subramanian, N., and D.S. Prakash Rao, "Design of Joints in RC Structures with Particular Reference to Seismic Conditions, The Indian Concrete Journal, Vol. 77, No. 2, Feb. 2003, pp. 883-892.

[2]. Jain, S.K., and C.V. R. Murty, (2002) 'Proposed Draft Provisions and Commentary on Ductile Detailing of RC Structures Subjected to Seismic Forces (IS 13920', Document No. IITKGSDMA-EQ11-V4.0, IITK-GSDMA Project on Building $\quad$ Codes, $\quad 67 \quad$ pp. http://www.iitk.ac.in/nicee/IITKGSDMA/EQ11.pdf -Accessed on 17th July 2013).

[3]. Hwang, S-J., H-J. Lee, T.-F. Liao, K.-C. Wang, and H.-H. Tsai, (2005), ' Role of hoops on Shear strength of Reinforced Concrete Beam-Column Joints', ACI Structural Journal, Vol.102, No.3, May-June 2005, pp.445-453.

[4]. Dhake Pravinchandra, Jape Anuja, Patil Hemant and Patil Yogesh "Behavior of exterior beam column joints with diagonal cross bars and headed bars "IJSCER Vol. 4, No. 1, February 2015

[5]. S. Rajagopal, S. Prabavathy - "Investigation on the seismic behavior of exterior

[6]. beam-column joint using T-type mechanical anchorage with hair-clip bar.", Journal of King Saud University - Engineering Sciences (2015) 27, 142-152.

[7]. A. K. Kaliluthin, S. Kothandaraman," Performance Evaluation of Exterior BeamColumn Joint with Core Reinforcement Technique Subjected to Reverse Cyclic Loading”, Arab J Sci Eng (2017) 42:3673-3687.

[8]. Gregoria Kotsovou , Harris Mouzakis - “ Exterior RC beam-column joints: New design approach.", Engineering Structures 41 (2012) 307-319.

[9]. S.M. Kulkarni, Y.D. Patil - “ A Novel Reinforcement Pattern for Exterior Reinforced 
Concrete Beam-Column Joint.", Procedia Engineering 51 ( 2013 ) pp. $184-193$.

Codes:

[10]. IS 456 (2000), "Code of Practice for Plain and Reinforced Concrete." Bureau of Indian standard,2000.

[11]. IS : 875 (Part 1) - 1987 " Code of Practice for design load(Other than Earthquake) for Buildings and Structures". Part 1 dead loads

[12]. IS : 875 (Part 2) - 1983 " Code of Practice for design load(Other than Earthquake) for Buildings and Structures". Part 2 imposed loads.

[13]. IS : 875 (Part 3) - 1987 " Code of Practice for design load(Other than Earthquake) for Buildings and Structures". Part 2 wind loads.

[14]. IS : 875 (Part 4) - 1987 " Code of Practice for design load(Other than Earthquake) for Buildings and Structures". Part 4 snow loads.

[15]. IS : 875 (Part 5) - 1983 " Code of Practice for design load(Other than Earthquake for Buildings and Structures". Part 5 special loads and combination.

[16]. IS : 875 (Part 5) - 2015 " Code of Practice for design load(Other than Earthquake for Buildings and Structures". Part 5 special loads and combination.

[17]. IS 5816 (1999): "Method of Test Splitting Tensile Strength of Concrete".

[18]. IS: 12269, "Specifications for 53 Grade Ordinary Portland Cement".

[19]. IS: 2386, "Methods of test for Aggregates for Concrete", reprinted 1997.

[20]. IS: 269, "Specifications for 33 Grade Ordinary Portland Cement".

[21]. IS: 383 (1970): "Specification for Coarse and Fine Aggregates From Natural Sources For Concrete".

Reference books :

[22]. Park, R., and Paulay, T. (1975), Reinforced Concrete Structures, John Wiley \& Sons, New York, 769 pp.

[23]. Paulay, T., R. Park, and M. J. N. Priestley (1992). 'Reinforced Concrete Beam-Column
Joints under Seismic Actions, ACI Journal, Vol. 75, No. 11, Nov. 1978, pp. 585-593.

[24]. Paulay, T. and M. J. N. Priestley 1992, Seismic Design of Reinforced Concrete and Masonry Buildings, John Wiley and Sons, New York, 744 pp.

\section{Cite this article as :}

Vrajesh M Patel, Dr. Suhasini Kulkarni, "A Review on Pull out Test on Exterior Beam-Column joint", International Journal of Scientific Research in Science, Engineering and Technology (IJSRSET), Online ISSN : 2394-4099, Print ISSN : 2395-1990, Volume 6 Issue 2, pp. 763-767, MarchApril 2019. Available at doi : https://doi.org/10.32628/IJSRSET218373 Journal URL : https://ijsrset.com/IJSRSET218373 